Louisiana State University

LSU Digital Commons

Faculty Publications

Department of Chemistry

$1-21-2004$

\title{
Visual Detection of Cysteine and Homocysteine
}

Oleksandr Rusin

Louisiana State University

Nadia N. St. Luce

Louisiana State University

Rezik A. Agbaria

Louisiana State University

Jorge O. Escobedo

Louisiana State University

Shan Jiang

Louisiana State University

See next page for additional authors

Follow this and additional works at: https://digitalcommons.Isu.edu/chemistry_pubs

\section{Recommended Citation}

Rusin, O., St. Luce, N., Agbaria, R., Escobedo, J., Jiang, S., Warner, I., Dawan, F., Lian, K., \& Strongin, R. (2004). Visual Detection of Cysteine and Homocysteine. Journal of the American Chemical Society, 126 (2), 438-439. https://doi.org/10.1021/ja036297t

This Article is brought to you for free and open access by the Department of Chemistry at LSU Digital Commons. It has been accepted for inclusion in Faculty Publications by an authorized administrator of LSU Digital Commons.

For more information, please contact ir@lsu.edu. 
Authors

Oleksandr Rusin, Nadia N. St. Luce, Rezik A. Agbaria, Jorge O. Escobedo, Shan Jiang, Isiah M. Warner, Fareed B. Dawan, Kun Lian, and Robert M. Strongin 


\title{
Visual Detection of Cysteine and Homocysteine
}

\author{
Oleksandr Rusin $^{\dagger} \ddagger$, Nadia N. St. Luce ${ }^{\dagger}$, Rezik A. Agbaria ${ }^{\dagger}$, Jorge O. Escobedo ${ }^{\dagger}$, Shan \\ Jiang $^{\dagger}$, Isiah M. Warner ${ }^{\dagger}$, Fareed B. Dawan ${ }^{\ddagger}$, Kun Lian ${ }^{\ddagger}$, and Robert M. Strongin ${ }^{\star}, \dagger$ \\ Department of Chemistry and Center for Advanced Microstructures and Devices, Louisiana State \\ University, Baton Rouge, Louisiana 70803
}

\begin{abstract}
Homocysteine is a risk factor for disorders including cardiovascular ${ }^{1}$ and Alzheimer's disease. ${ }^{2}$ Cysteine deficiency is involved in slowed growth, hair depigmentation, edema, lethargy, liver damage, muscle and fat loss, skin lesions, and weakness. ${ }^{3}$ The detection of important biological thiols including cysteine and homocysteine has been the focus of numerous research efforts. ${ }^{4}$ The majority of the reported methods are based on redox chemistry or derivatization with chromophores or fluorophores. The determination of specific thiols is often carried out in conjunction with HPLC or capillary electrophoresis separations or via immunoassays. ${ }^{4}$ Recent reports describe a need for much simpler methods that employ stable, nontoxic reagents ${ }^{5 \mathrm{a}, \mathrm{b}}$ which are less sensitive to $\mathrm{pH}^{5 \mathrm{c}}$ and afford the requisite sensitivity ${ }^{5 \mathrm{~d}, 6 \mathrm{a}}$ as well as high selectivity. ${ }^{6 \mathrm{~b}}$
\end{abstract}

We have reported prior progress toward the colorimetric and fluorimetric detection of monoand oligosaccharides. ${ }^{7}$ Our studies featured new functionalized xanthenes which we found arose in situ from ring-opened resorcinarenes and related materials. ${ }^{7 \mathrm{c}}$ Our interest in the title compounds derives initially from the interference of cysteine with known sialic acid determinations. ${ }^{8}$ Herein we report the use of xanthene dye $\mathbf{1}^{9}$ for the efficient detection of cysteine and homocysteine.

The selective reaction of aldehydes with $\mathrm{N}$-terminal cysteines to form thiazolidines has been used to label and immobilize peptides and proteins. ${ }^{10}$ Compound $\mathbf{1}$ was employed as an intermediate toward the synthesis of a fluorescent sensor for zinc. ${ }^{9}$ We reasoned that the reaction of the aldehyde moieties of $\mathbf{1}$ with cysteine or homocysteine would promote readily monitored colorimetric and fluorometric responses (Scheme 1).

We find that upon addition of ${ }_{\mathrm{L}}$-cysteine or $\mathrm{L}_{\text {-homocysteine }}\left(1.0 \times 10^{-3} \mathrm{M}\right)$ to a solution of $\mathbf{1}$ $\left(1.0 \times 10^{-6} \mathrm{M}, \mathrm{H}_{2} \mathrm{O}, \mathrm{pH} 9.5\right)$, a solution color change from bright yellow to brownish-orange is observed. Similar color changes are observed on $\mathrm{C}_{18}$-bonded silica (Figure 1). UV-vis absorbance changes of cysteine- 1 solutions, readily monitored in the $10^{-5}-10^{-6} \mathrm{M}$ cysteine concentration range, exhibit a $25 \mathrm{~nm}$ red shift. ${ }^{11-13}$ Addition of $\mathbf{2 a}$ or $\mathbf{2 b}$ to solutions of $\mathbf{1}$ results in fluorescence quenching. ${ }^{13}$

Respective solutions of $\mathbf{1}$ containing identical concentrations of $\mathbf{2 a}$ and $\mathbf{2 b}$ exhibit similar spectrophotometric changes (Figure 2). UV-vis spectra of solutions containing $\mathbf{1}$ and other common thiols ( $\mathrm{L}-\mathrm{methionine}$, mercaptoethanol, glutathione), other amino acids (L-

\footnotetext{
(C) 2004 American Chemical Society

*rstrong@1su.edu.

$\dagger$ Department of Chemistry.

\$Center for Advanced Microstructures and Devices.
}

Supporting Information Available: UV-vis and fluorescence spectra of 1, 2a,b, and 3a,b in aqueous and plasma solutions, UV-vis spectra of various thiols, aminesf and protein analytes in solutions containing $\mathbf{1}$, and ${ }^{1} \mathrm{H}$ NMR spectra of $\mathbf{1}$ and $\mathbf{3 a}$,b (PDF). This material is available free of charge via the Internet at http://pubs.acs.org. 
glutamine, L-serine, L-glycine, L-glutamic acid), and amines (D-glucosamine hydrochloride and $n$-propylamine $\left(8.0 \times 10^{-4} \mathrm{M}, \mathrm{pH} 9.5\right)$ confirm the selectivity of $\mathbf{1}$ for cysteine and homocysteine. ${ }^{13}$

At most a $15 \%$ change in absorbance at $480 \mathrm{~nm}$ is observed in response to the aforementioned analytes. No wavelength shift occurs. Solutions containing 1 and bovine serum albumin or urease $\left(8.0 \times 10^{-4} \mathrm{M}, \mathrm{pH} 9.5\right)$ also exhibit relatively small absorbance $(<15 \%)$ decreases and no $\lambda_{\max }$ shifts. ${ }^{13}$

The addition of L-cysteine to a sample of commercial human blood plasma (previously centrifuged at $3000 \mathrm{~g}$ through a cellulose $3000 \mathrm{MW}$ cutoff filter, the low-molecular-weight fraction is used for analysis), containing 1 and excess glutathione $(1.0 \mathrm{mM})$, results in concentration-dependent UV-vis changes (Figure 3). Figure 4 shows a linear correlation between fluorescence emission intensity and healthy to abnormal homocysteine concentrations in plasma containing $\mathbf{1} .^{6 \mathrm{a}}$ This demonstrates the potential utility of $\mathbf{1}$ toward calibrating and determining aminothiol concentrations in plasma samples in the presence of other biological thiols.

In conclusion, compound $\mathbf{1}$ can be used to readily detect L-cysteine and L-homocysteine in the range of their physiological levels. ${ }^{6 a}$ Interference from amines, amino acids, and certain thiols and proteins is minimal. The methodology shows great promise for the fluorescence and UV-vis detection of aminothiols in plasma.

\section{Supplementary Material}

Refer to Web version on PubMed Central for supplementary material.

\section{Acknowledgments}

We gratefully acknowledge the National Institutes of Health (8R01EB002044-03) for support of this research. We also thank Professor S. J. Lippard and members of his research group at MIT for helpful advice concerning the synthesis of $\mathbf{1}$ and congeners.

\section{References}

(1). Review: Refsum H, Ueland PM, Nygård O, Vollset SE. Annu. Rev. Med. 1989; 49:31. [PubMed: 9509248]

(2). Seshadri S, Beiser A, Selhub J, Jacques PF, Rosenberg IH, D'Agostino RB, Wilson PWF. N. Engl. J. Med. 2002; 346:476. [PubMed: 11844848]

(3). Shahrokhian S. Anal. Chem. 2001; 73:5972. [PubMed: 11791568]

(4). Recent review: Nekrassova O, Lawrence NS, Compton RG. Talanta. 2003; 60:1085. [PubMed: 18969134]

(5). For example: Amarnath V, Amarnath K. Talanta. 2002; 56:745. [PubMed: 18968551] Ercal N, Yang P, Aykin N. J. Chromatogr. B. 2001; 753:287. Ivanov AR, Nazimov IV, Baratova LA. J. Chromatogr. A. 2000; 870:433. [PubMed: 10722099] Pasas SA, Lacher NA, Davies MI, Lunte SM. Electrophoresis. 2002; 23:759. [PubMed: 11891709]

(6). (a) Healthy plasma total homocysteine concentrations are ca. $12 \mu \mathrm{M}$. Cysteine concentrations are typically 20-30 times that of homocysteine (see refs 1 and 2). (b) The relatively large excess of glutathione present in biological samples can complicate the detection of other less abundant thiols.

(7). (a) Davis CJ, Lewis PT, McCarroll ME, Read MW, Cueto R, Strongin RM. Org. Lett. 1999; 1:331. [PubMed: 10905872] (b) Lewis PT, Davis CJ, Cabell LA, He M, Read MW, McCarroll ME, Strongin RM. Org. Lett. 2000; 2:589. [PubMed: 10814385] (c) He M, Johnson R, Escobedo JO, Beck JA, Kim KK, St. Luce NN, Davis C. J.; Lewis PT, Fronczek F. R.; Melancon BJ, Mrse AA, Treleaven WD, Strongin RM. J. Am. Chem. Soc. 2002; 124:5000. [PubMed: 11982364] 
(8). Warren L. J. Biol. Chem. 1959; 234:1971. [PubMed: 13672998] (b) We are developing new methods for the detection of sialic acid, an important cell surface residue; see refs $7 \mathrm{a}$ and $7 \mathrm{c}$.

(9). Burdette SC, Walkup GK, Spingler B, Tsien RY, Lippard SJ. J. Am. Chem. Soc. 2001; 123:7831. [PubMed: 11493056]

(10). Tolbert TJ, Wong C-H. Angew. Chem., Int. Ed. 2002; 41:2171. and references therein. Reactions of carbonyls with cysteine and homocysteine: Fourneau JP, Efimovsky O, Gaignault JC, Jacquier R, LeRidant C. C. R. Acad. Sci. Ser. C. 1971; 272:1982. Cooper AJL, Meinster A. J. Biol. Chem. 1982; 257:816. [PubMed: 7054184]

(11). The conversion of $\mathbf{2} \mathbf{a}$ and $\mathbf{2} \mathbf{b}$ to thiazolidine dicarboxylic acids $\mathbf{3 a}$ and $\mathbf{3 b}$ is confirmed by $1 \mathbf{H}$ NMR. Reaction of 1 with propylamine or glucosamine ( $1: 2$ ratio of $\mathbf{1}$ to analyte, $\mathrm{D}_{2} \mathrm{O}$ ) results in a diminishing aldehyde resonance (10.2 ppm) of $\mathbf{1}$ and the appearance of imine resonances centered at $9.6 \mathbf{~ p p m}$. When $\mathbf{2 a}$ or $\mathbf{2} \mathbf{b}$ is added to solutions of $\mathbf{1}$, imine resonances are observed at ca. $9.6 \mathrm{ppm}$ which diminish over time (5 min). New resonances centered at 6.13 and $6.04 \mathrm{ppm}$ appear, which we assign to the methine protons of the thiazolidine diastereomers $3 \mathbf{a}$ and $\mathbf{3 b}$, respectively. Complete conversion to bis-thiazolidines $\mathbf{3 a}$ and $\mathbf{3 b}$ is evidenced by a $2: 2$ ratio of the integral areas of the new methine protons to the chromophore aromatic proton resonances as well as complete disappearance of the starting aldehyde and intermediate imine resonances. No evidence of aromatic heterocycle formation is observed. The formation of $\mathbf{3 a}$ and $\mathbf{3 b}$ is also confirmed by mass spectrometry: 3a MALDI TOF MS, calcd for $\mathrm{C}_{28} \mathrm{H}_{21} \mathrm{~N}_{2} \mathrm{O}_{9} \mathrm{~S}_{2} \mathrm{Na}(\mathrm{M}+\mathrm{Na})^{9}$ 618.61, found 618.42; 3b FAB MS, calcd for $\mathrm{C}_{30} \mathrm{H}_{25} \mathrm{~N}_{2} \mathrm{O}_{9} \mathrm{~S}_{2} \mathrm{Na}(\mathrm{M}+\mathrm{Na})^{+} 646.66$, found 646.80 (see also Supporting Information).

(12). We obtain analogous absorption spectra under identical conditions at $\mathrm{pH} 6.5$; however, we observe minor amounts of precipitate.

(13). See Supporting Information.

(14). Deproteinization is typically performed before biological thiol analysis: Caussé E, Issac C, Malatray P, Bayle C, Valdiguié P, Salvayre R, Couderc F. J. Chromatogr. A. 2000; 895:173. [PubMed: 11105859] 


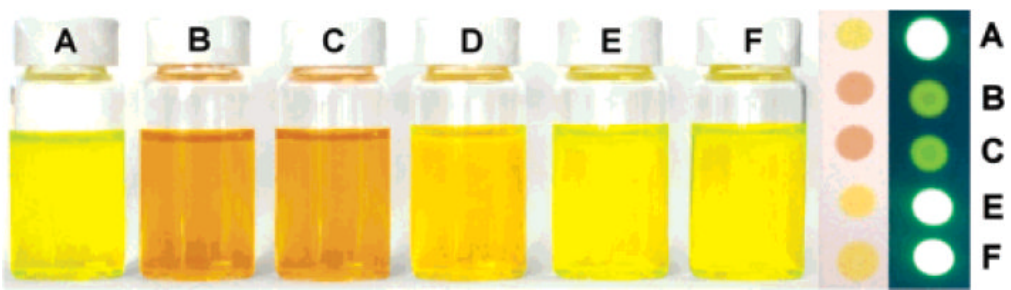

Figure 1.

(Left) Color changes of solutions of $\mathbf{1}$ and various analytes. A, no analyte; B, L-cysteine; C, L-homocysteine; D, bovine serum albumin; E, L-glycine; and F, n-propylamine. (Right) Cospots of $\mathbf{1}\left(1.0 \times 10^{-3} \mathrm{M}\right)$ with and without various analytes $\left(1.0 \times 10^{-3} \mathrm{M}\right)$ under visible and UV light. 


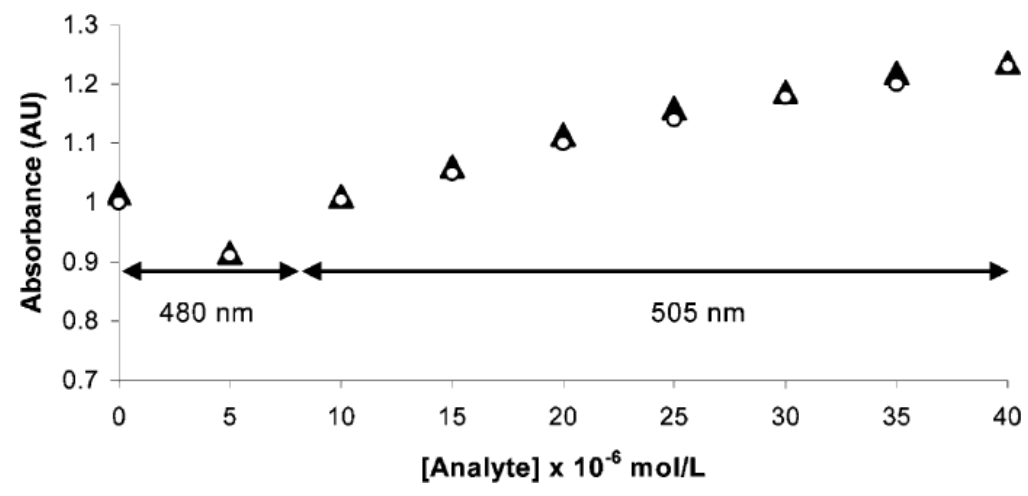

Figure 2.

Absorbance vs concentration plots for ${ }_{L}$-cysteine $(\boldsymbol{A})$ or $_{\mathrm{L}}$-homocysteine $(\bigcirc)$ in aqueous solutions of $1\left(2.5 \times 10^{-6} \mathrm{M}\right)$ at $\mathrm{pH} 9.5$. The figure highlights the similarity of the absorbance responses of $\mathbf{1}$ to $\mathbf{2 a}$ and $\mathbf{2 b}$. An absorbance decrease is shown at $480 \mathrm{~nm}$ for $\mathbf{2 a}$ and $\mathbf{2 b}$ at $5.0 \times 10^{-6} \mathrm{M}$ concentrations, while the absorbance increase is shown at $505 \mathrm{~nm}$ for increasing concentrations of $\mathbf{2 a}$ and $\mathbf{2 b}$ from $10 \times 10^{-6}$ to $40 \times 10^{-6} \mathrm{M}$. 


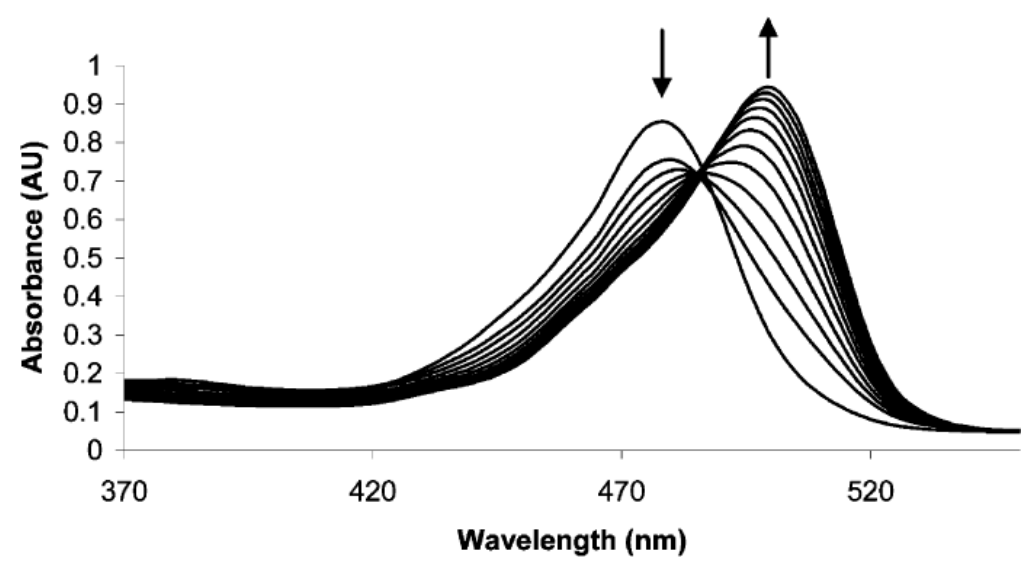

Figure 3.

UV-vis spectra of $1\left(4 \times 10^{-6} \mathrm{M}\right)$ and $\mathrm{L}_{\text {-cysteine }}\left(4.9 \times 10^{-5}-7.4 \times 10^{-4} \mathrm{M}\right)$ in deproteinized human plasma at room temperature containing $1.0 \mathrm{mM}$ added glutathione ( $\mathrm{pH} 9.5)$. Each spectrum is acquired $5 \mathrm{~min}$ after cysteine addition. As the concentration of $\mathrm{L}_{\text {-cysteine }}$ increases, a red shift from 480 to $500 \mathrm{~nm}$ is observed. 


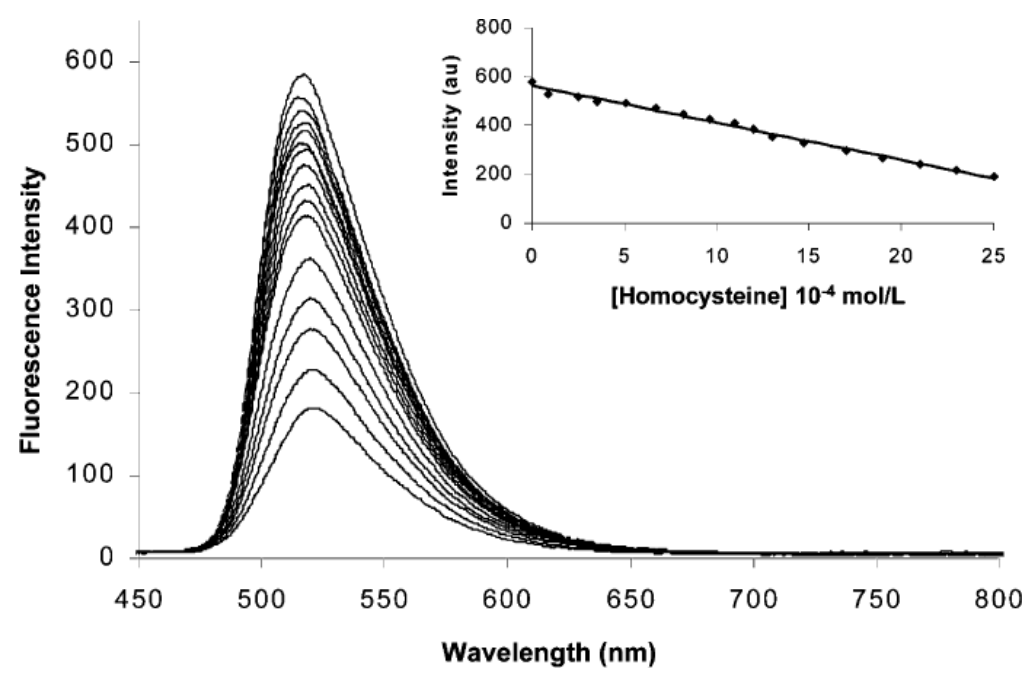

Figure 4.

Fluorescence emission spectra of $1\left(5.2 \times 10^{-7} \mathrm{M}\right)$ and L-homocysteine $\left(2.9 \times 10^{-6}-2.510^{-3}\right.$ M) in deproteinized human plasma excited at $460 \mathrm{~nm}$ ( $\mathrm{pH} 9.5$ ). (Inset) Fluorescence emission plotted vs [2b]. 
<smiles>O=Cc1c2oc3c(C=O)c(O)ccc3c(-c3ccccc3C(=O)[O-])c-2ccc1=O</smiles>

1
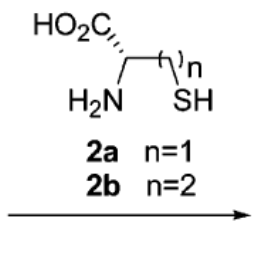

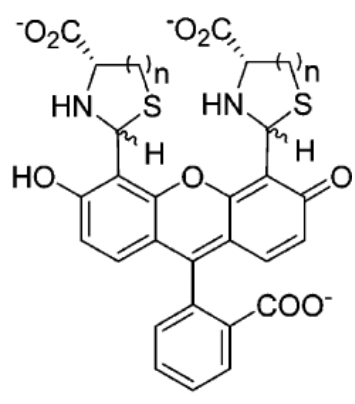

3a $n=1$

3b $n=2$

Scheme 1. 